\title{
\begin{tabular}{l|l} 
Mibraries & DSpace@MIT
\end{tabular}
}

\author{
MIT Open Access Articles
}

Beyond the Sea-Land Divide: A World Map

The MIT Faculty has made this article openly available. Please share how this access benefits you. Your story matters.

Citation: Segal, Rafi, and Yonatan Cohen. "Beyond the Sea-Land Divide: A World Map." Grey Room 57 (October 2014): 50-55. ( 2014 by Grey Room, Inc. and the Massachusetts Institute of Technology

As Published: http://dx.doi.org/10.1162/GREY_a_00157

Publisher: MIT Press

Persistent URL: http://hdl.handle.net/1721.1/98490

Version: Final published version: final published article, as it appeared in a journal, conference proceedings, or other formally published context

Terms of Use: Article is made available in accordance with the publisher's policy and may be subject to US copyright law. Please refer to the publisher's site for terms of use. 

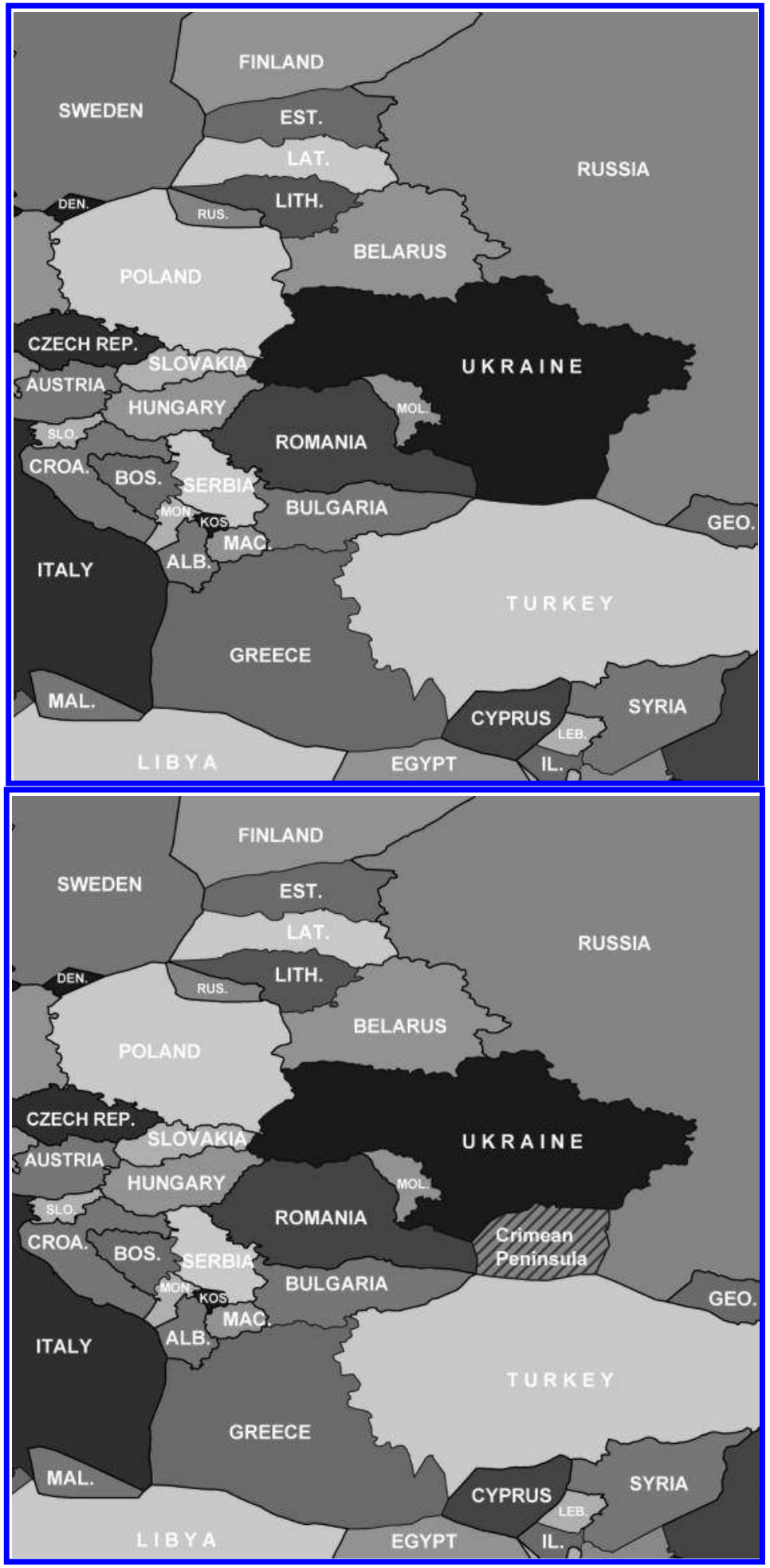

Rafi Segal and Yonatan Cohen.

Territorial Map of the World, 2013.

Detail showing the Black Sea

region before (top) and after

(bottom) the Russian annexation of the Crimean Peninsula.

Pages 52-55:

Rafi Segal and Yonatan Cohen.

Territorial Map of the World, 2013. 


\section{Beyond the Sea-Land Divide: A World Map}

\section{RAFI SEGAL AND YONATAN COHEN}

This political map of the world depicts the extent of territories, both on land and at sea (submerged lands), that are under the control of all independent nations. The boundaries shown combine national borders with their respective Exclusive Economic Zones (EEZ) but exclude the world's coastlines. EEZs are areas defined by international law as maritime territories lying within 200 nautical miles perpendicular to the coast and delimited by international treaties. The marine borders used in this map are based on a geometric projection of the maritime boundaries depicted by the Flanders Marine Institute (http://www.marineregions.org/eez.php). This map is not to be taken as the endorsement of one claim over another.

Coastlines-linear entities dividing land from water-were historically one of the first geographical features to be represented accurately in maps, thus becoming a common datum for the development of seafaring, charting technology, and the history of exploration more generally. The twentieth century brought about profound changes in the organization and measurement of the world. The rudimentary divide of water and land became an obsolete artifact of mapping, both irrelevant to evolving political and economic concepts of space and useless in settling claims of national sovereignty over sea zones. (The recent takeover of Crimea by Russia is a case in point.) The world as it is envisioned today-and depicted in this map-is a continuous space where the movement of people and information overrides the once-constitutive barrier between land and sea, and is regulated instead by hybrid politico-legal constructs.

Augmenting the familiar shapes of nation-states, the map evokes a world that has evolved beyond the land-sea divide. The seas today are a territory of potentialities: for the production of wild and cultivated food; for the extraction of minerals and fossil fuels; and for the future harvesting of energy. By rendering the areas of control and supervision over the use of sea zones, this map reveals the new reality of the world's division of resources and outlines the present areas of environmental responsibility (in which land and sea are intrinsically tied) and the possible future places of territorial conflict. As such, the map expands our perception and comprehension of political space and offers a tool for negotiation in advance of confrontations yet to surface. 


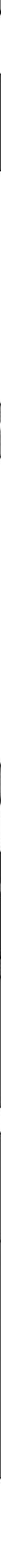




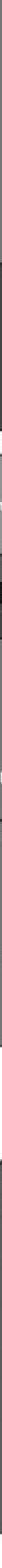

\section{NORTH PACIFIC} OCEAN (unclaimed)

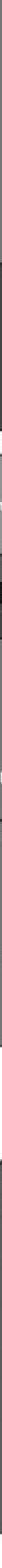

UNITED STATES 


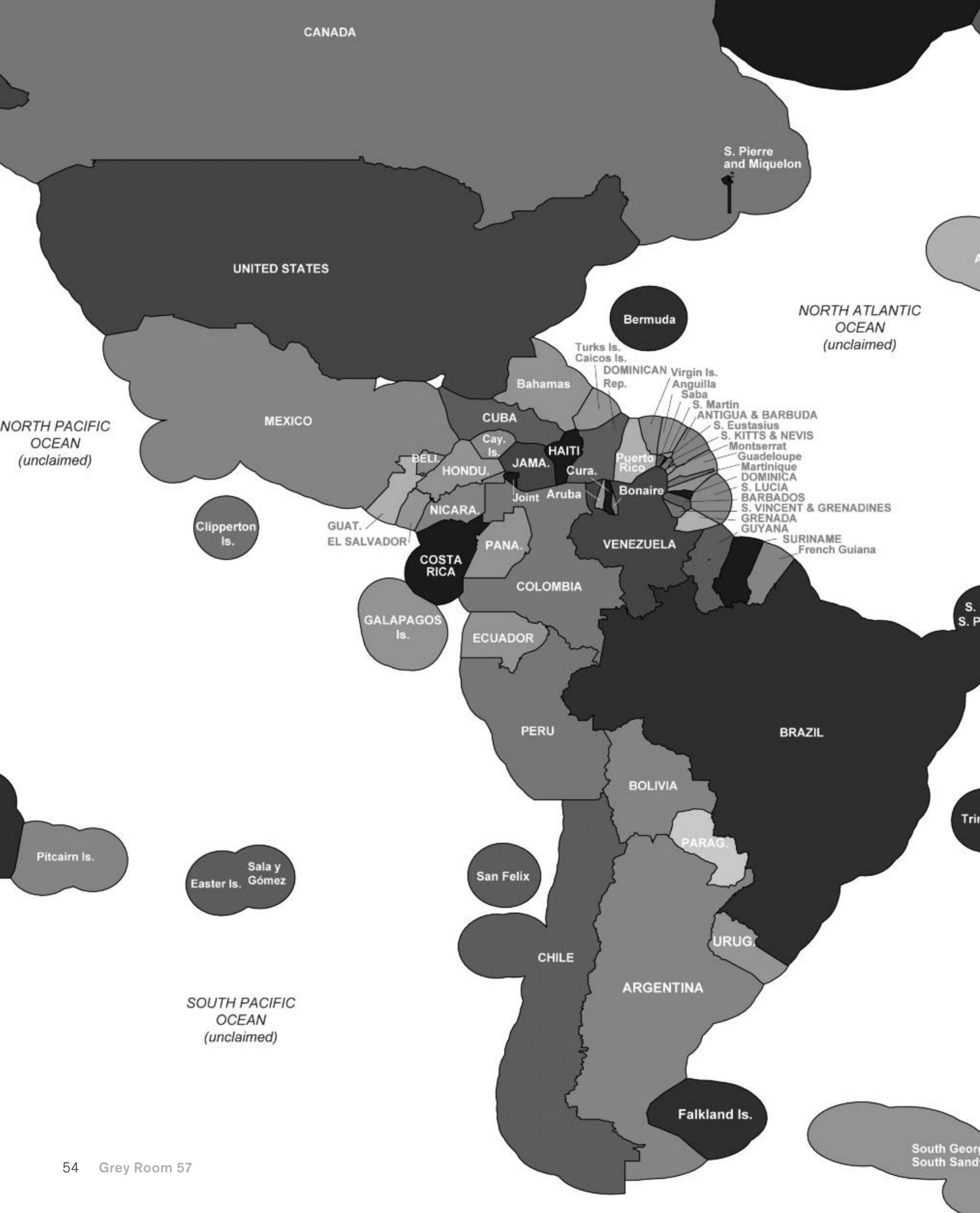


